\title{
The Effect of Non-Native Black Pine (Pinus nigra J. F. Arnold) Plantations on Environmental Conditions and Undergrowth Diversity
}

\author{
Katarína Mikulová ${ }^{1, * \mathbb{C}}$, Ivan Jarolímek ${ }^{1}$, Tomáš Bacigál ${ }^{2}{ }^{\mathbb{D}}$, Katarína Hegedüšová ${ }^{1}$, \\ Jana Májeková ${ }^{1}$, Jana Medvecká ${ }^{1}$, Denisa Slabejová ${ }^{1}$, Jozef Šibík ${ }^{1}{ }^{\mathbb{D}}$, Iveta Škodová ${ }^{1}$, \\ Mária Zaliberová ${ }^{1}$ and Mária Šibíková ${ }^{1}$ (D) \\ 1 Institute of Botany, Plant Science and Biodiversity Centre, Slovak Academy of Sciences, Dúbravská cesta 9, \\ 84523 Bratislava, Slovakia \\ 2 Department of Mathematics and Descriptive Geometry, Faculty of Civil Engineering, \\ Slovak University of Technology, Radlinského 11, 81368 Bratislava, Slovakia \\ * Correspondence: katarina.botkova@savba.sk; Tel.: +421-259426179
}

Received: 23 May 2019; Accepted: 26 June 2019; Published: 29 June 2019

check for updates

\begin{abstract}
The cover of introduced tree species in Europe has recently increased, due to several factors. Attempts to understand the impact of non-native edificator trees on the environmental conditions and diversity of undergrowth have so far been limited to a few studies. In this paper, we analyse the effect of one of the most commonly planted non-native tree species-black pine (Pinus nigra J. F. Arnold) in the Carpathian-Pannonian region, north of the border of its native occurrence. The objectives of our study were to determine the following: (i) How does black pine, as a non-native edificator, change the forest structure and environmental conditions in comparison to those of native communities? (ii) How does black pine change the species composition of undergrowth in comparison to that of native communities? (iii) Which factors are associated with the impact of black pine on diversity? To answer these questions, we used the twin plot method, sampling two neighbouring plots with the same environmental conditions in which one plot of the pair is in a forest with native tree species composition and the second plot is in a planted non-native Pinus nigra plantation. We found that in forests dominated by the non-native black pine, (a) the tree canopy is significantly more open; (b) the cover of the shrub layer is significantly higher; (c) the needles of black pine form a significantly thicker litter layer and (d) the cover of the herb layer is significantly lower than that in the native forest. (e) Black pine plays a vital role in modifying local climate by altering air temperature and humidity; ( $f$ ) there were no significant differences in the soil $\mathrm{pH}$ between black pine plantations and native forests; (g) the plantations of black pine cause changes in diversity at both the species and the community level and $(\mathrm{h})$ the dissimilarity between black pine plantations and neighbouring native forests decreases at higher altitudes.
\end{abstract}

Keywords: coniferous; deciduous; diagnostic species; diversity; edificator; local climate; non-native species; Pinus nigra; plantation; species composition

\section{Introduction}

Managed forests, especially in temperate zones, cover a large proportion of the total forest area [1]. One of the fundamental roles of foresters is selecting the tree species composition. Edificator species, species which have the great effect on the environment and, through it, on the other plants in the community, depending on their identity and level of dominance, influence the understory vegetation diversity and composition [2,3]. As a part of this effect, edificator species represent important factors affecting the spread and occurrence of non-native plants in forests [4]. 
Plantations of non-native trees form an important part of European forests. Introduced tree species in Europe cover an area of over 9.5 million ha, 4.4 percent of the total European forest area [1]. Some introduced tree species make significant contributions to wood production in many countries. Nevertheless, understanding the impact of non-native edificator trees on the environmental conditions and the diversity of undergrowth has so far been limited to a few studies [5-8].

In this paper, we analyse the effect of Pinus nigra J. F. Arnold, one of the most commonly planted tree species outside its native range as well [1]. Its distribution area extends to the sub-Mediterranean region, southern Europe and Asia Minor, and some isolated localities in North Africa as well. Its northernmost occurrence is on the southern slopes of the Alps [9]. The optimal altitude for black pine is $800-1500 \mathrm{~m}$ above sea level, but it can survive at a much wider altitudinal range [10]. Pinus nigra can grow on a variety of soils, from podzolic sands to limestone, often depending on region and climate; it can grow in both extremely dry and humid habitats with a considerable tolerance for temperature fluctuations. It is a light-demanding species, but it shows higher shade tolerance than Scots pine (Pinus sylvestris L.). It is resistant to drought and wind [9].

Black pine is planted in various habitats outside its native range-from xerotherm localities to mesophilous forests to floodplain forests. It is used for its quality timber, for sand dune fixation, as a windbreak and as an ornamental and pollution-tolerant tree in cities [9]. As black pine was planted on erosion slopes and abandoned agricultural land in the twentith century, it is possible to find it in such locations today [11]. It is apparent that black pine plantations have become widespread important factors in the landscape that could affect various forest ecosystems in different ways. Despite these facts, there is still a lack of information about the effects of black pine on various environments.

In Central Europe, replacing native forests with black pine represents a specific situation in which previously broadleaved deciduous forests are replaced by coniferous forests. In black pine plantations, an edificator species shows large morphological and phenological plasticity and different structure of leaves/needles, resulting in different compositions of the litter with longer periods of decomposition compared to native deciduous forests [12]. Different habitus and phenological phases have the potential to change the light availability and microclimate of forest patches, while changes in litter composition could affect soil $\mathrm{pH}$. These changes modify the environment in black pine plantations and strongly influence the forest undergrowth.

To assess the effect of black pine planted outside its native range in the role of an edificator species, we analysed a large dataset containing pairs of plots from forests with native tree species composition and non-native Pinus nigra plantations.

This paper addresses the following questions: (i) How does black pine, in its function as a non-native edificator, change the structure and environmental conditions in comparison to those of native communities? (ii) How does black pine change the species composition of undergrowth in comparison to that of native communities? (iii) Which factors are associated with the impact of black pine on diversity?

\section{Materials and Methods}

\subsection{Data Collection}

The studies were conducted in the Carpathian-Pannonian region, across the Czech Republic, Hungary, Slovakia, and Ukraine (Figure 1), north of the border of the native occurrence of Pinus nigra. The study area is located in the transition zone between temperate oceanic and temperate continental climates. 


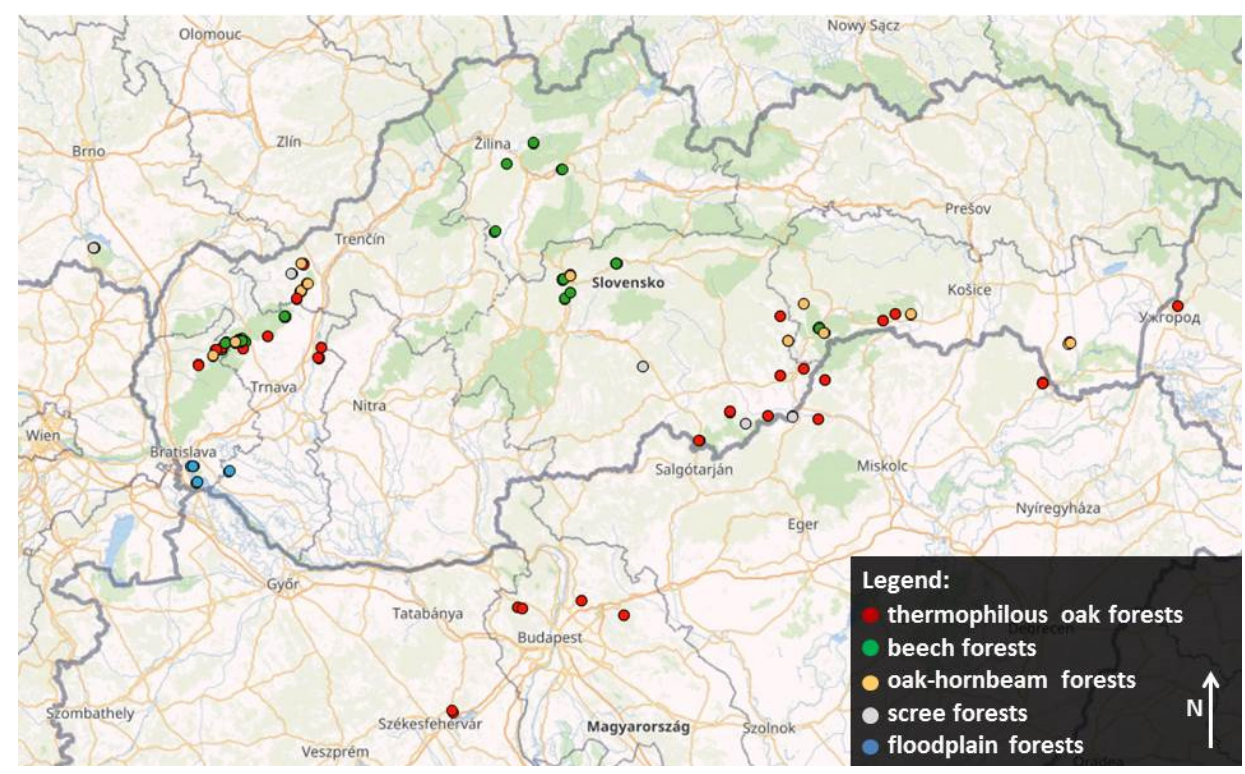

Figure 1. Distribution of twin plots. In colour, according to the native twin plot classification within higher syntaxa. Thirty twin plots of Pinus nigra plantations vs. thermophilous oak forests (Quercion pubescenti-petraeae, Quercion petraeae, Aceri tatarici-Quercion); 27 twin plots of Pinus nigra plantations vs. beech forests (Luzulo-Fagion sylvaticae, Fagion sylvaticae); 16 twin plots of Pinus nigra plantations vs. oak-hornbeam forests (Carpinion betuli); nine twin plots of Pinus nigra plantations vs. scree forests (Tilio-Acerion, Melico-Tilion platyphylli); and three twin plots of Pinus nigra plantations vs. floodplain forests (alliance Salicion albae, Fraxino-Quercion roboris), base map (C) OpenStreetMap Contributors.

Data collection was based on the twin plot method (Bazalová et al. 2018 [13]): Sampling of two neighbouring plots with similar environmental conditions (aspect, slope, altitude, bedrock, sampled on the same date, the similar age of stands) where one plot of the pair is sampled in a forest with native tree species composition, and the second plot is sampled in a planted non-native Pinus nigra plantation (Figure 2). The centres of the plots should be at a maximum distance of $250 \mathrm{~m}$ to maintain the same local environmental conditions. Thus, the differences between the twin plots can be considered as a consequence of the changed tree edificator species. Suitable sites for twin plots were found using the forestry GIS of Slovakia (http://gis.nlcsk.org/lgis/) [14] and satellite maps using NaturaSat software (Mikula et al. in prep.), recommendations of stakeholders and our own field research in the Czech Republic, Hungary and Ukraine. All Pinus nigra forests sampled during our research was planted by foresters, in the areas of previous native forests and have a cover of tree layer higher than $50 \%$. Only plantations on forest land were sampled. There are also some Pinus nigra stands in study region planted on abandoned pastures or vineyards on steep slopes and south orientation. These localities have different habitus - the low cover of tree layer (less than 50\%) and many dry grassland species in the undergrowth. Such secondary forests differ from plantations replacing native forests, thus, they were not sampled. Plots were collected on equal-sized plots $(20 \mathrm{~m} \times 20 \mathrm{~m})$ for which lists of all vascular plant species with their cover estimated by the extended 9-degree Braun-Blanquet cover-abundance scale $[15,16]$ were recorded. For each plot, the cover of the individual vegetation layers and the cover and thickness of the litter layer were recorded. Light conditions were measured using the Gap Light Analysis Mobile Application (GLAMA) [17], with which a mean value of five measurements per plot was used (four near corners, and one in the middle of the plot). Slope and aspect were measured in the field by clinometer and compass. The obtained variables were supplemented by $\mathrm{pH}$ data from the upper part of the soil from collected soil samples (29 pairs), and the data were collected during the vegetation seasons of 2015-2017. Using these methods, we obtained 87 twin plots (174 plots) from five different vegetation groups: Five twin plots of Pinus nigra plantations vs. floodplain forests (alliance Salicion albae Soó 1951, Fraxino-Quercion roboris Passarge 1968); 30 twin plots of Pinus nigra plantations 
vs. thermophilous oak forests (Quercion pubescenti-petraeae Br.-Bl. 1932, Quercion petraeae Issler 1931, Aceri tatarici-Quercion Zólyomi 1957); 16 twin plots of Pinus nigra plantations vs. oak-hornbeam forests (Carpinion betuli Issler 1931); nine twin plots of Pinus nigra plantations vs. scree forests (Tilio-Acerion Klika 1955, Melico-Tilion platyphylli Passarge et G. Hofmann 1968); and 27 twin plots of Pinus nigra plantations vs. beech forests (Luzulo-Fagion sylvaticae Lohmeyer et Tx. in Tx. 1954, Fagion sylvaticae Luquet 1926). The distribution of the sampled plots is shown in Figure 1.

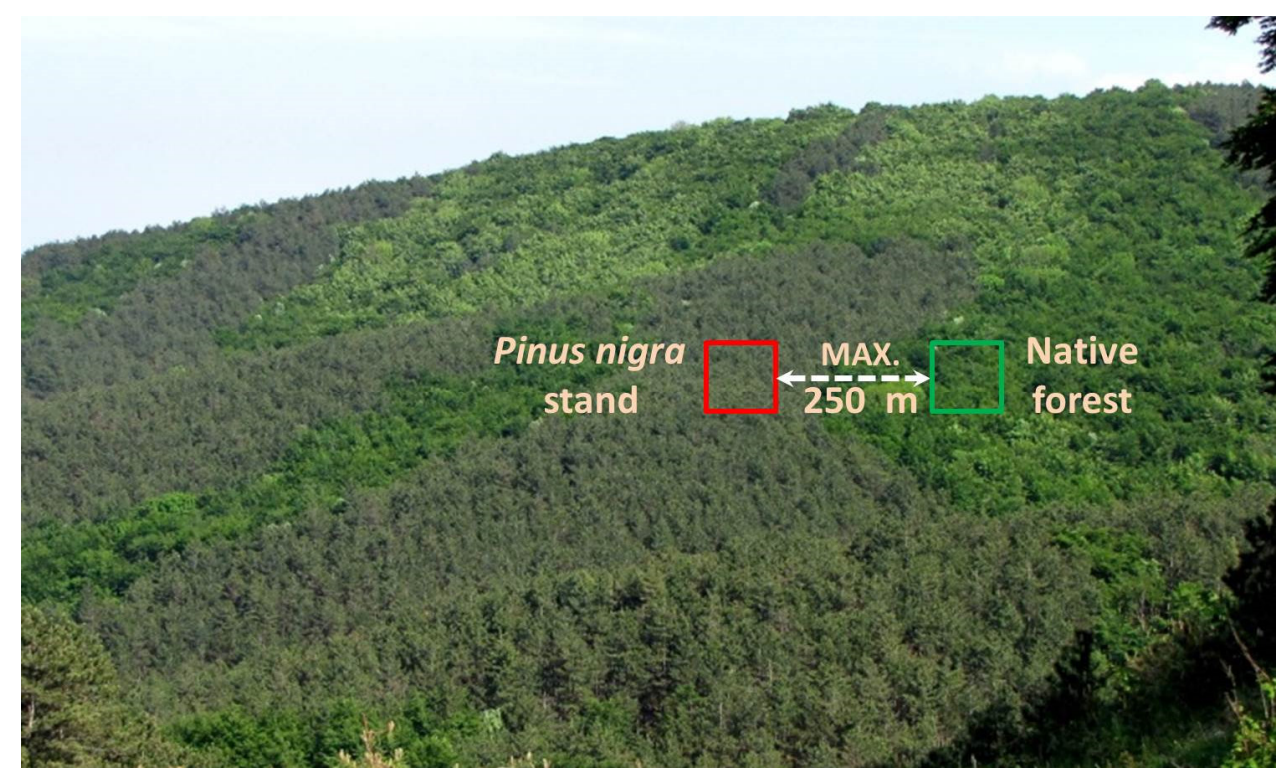

Figure 2. An example of the position of plots obtained by the twin plot method.

The data on microclimate in 30 selected representative twin plots were measured by data loggers (LogTag ${ }^{\circledR}$ HAXO-8, LogTag Recorders, Auckland, New Zealand) placed at a 4-5 m height above the ground on a tree branch protected by the cover from direct sunlight and rain. The data loggers automatically recorded temperature and air humidity in one-hour intervals from the beginning of April 2018 to the end of October 2018.

The plots were stored in TURBOVEG database [18], processed in Juice software ver. 7.0 [19] and analysed in R software [20]. Nomenclature of vascular plants follows Euro+Med [21]; nomenclature of syntaxa follows Mucina, et al. [22].

\subsection{Data Analyses}

The unweighted arithmetic mean of Ellenberg indicator values [23] for temperature, light, moisture, number of nutrients, and soil reaction was calculated for each plot. These values were calculated after the exclusion of neophyte species and the tree layer to detect the differences in the undergrowth. Ellenberg's indicator values were defined for Central European flora and have been widely employed and validated for the interpretation of the variation among plant communities in space and time in many European countries. Species that were absent or not assigned to a particular indicator value in the Ellenberg tables were omitted.

Archaeophyte and neophyte species were determined according to Pyšek, et al. [24] for the Czech Republic, Terpó, et al. [25] and Balogh, et al. [26] for Hungary, Medvecká et al. [27] for Slovakia and Protopopova [28] and Protopopova et al. [29] for Ukraine. The absolute number, relative abundance and cover of native species, neophytes and archaeophytes of undergrowth were calculated. For each plot, the absolute number, relative abundance and cover of diagnostic and constant species for corresponding alliances were calculated according to relevant phytosociological literature [30-32].

Structural (the cover of tree, shrub and herb layers), environmental (the cover and thickness of the litter layer), and light conditions were measured using GLAMA. Ellenberg indicator values and directly 
measured soil $\mathrm{pH}$ ) and diversity characteristics (the absolute number, relative abundance and cover of native species, neophytes, archaeophytes, diagnostic and constant species for native communities) were compared between the twin plots using the Wilcoxon pair test, because the data showed non-normal distributions - as indicated by Shapiro-Wilk test in R software [20]. Significant results are visualised as box-plot graphs, which were made using the ggplot2 package of $\mathrm{R}$ software [33]. Each forest type could be influenced in a different way, but the analyses of vegetation groups separately will be not statisticaly adequate, while groups of some types are not statisticaly large enough. For an illustration of possible differences between vegetation groups in the above mentioned characteristics, we compared the differences of characteristics using Kruskal-Wallis non-parametric Analyses of Variance and post hoc multiple comparisons of mean ranks for all groups. All p-values were considered significant at $<0.01$.

Data on annual precipitation, radiation, temperature and altitude were obtained for each twin using QGIS [34]. Air temperature at $2 \mathrm{~m}$ was developed by GeoModel Solar from the Climate Forecast System Reanalysis and Global Forecast System databases (National Centers for Environmental Prediction, Berwyn, MD, USA). Precipitation data were derived by GeoModel Solar from the database of the Global Precipitation Climatology Centre project (National Center for Atmospheric Research, Boulder, CO, USA). Solar radiation was calculated by GeoModel Solar from the satellite and atmospheric data.

While annual precipitation, temperature and altitude were correlated (using the Spearman coefficient), the only altitude was used in the final analyses. The Bray-Curtis dissimilarity of each twin was calculated to quantify the dissimilarity between the twin plot. The influence of altitude, slope, radiation, aspect (using cardinal and intercardinal directions) and syntaxonomical alliances of the native forest on Bray-Curtis dissimilarity of twins was tested using a generalised linear model (GLM) with a quasibinomial distribution family and logit link function. The ideal model was chosen according to the $\mathrm{F}$ test.

The significance of differences in species composition of undergrowth between Pinus nigra and native forests was tested using PERMANOVA-Permutational analysis of variance (Bray-Curtis, 999 permutations). A synoptic table with frequencies and fidelity values [35] was generated to show the differences in species composition of groups.

The differences in hourly measured temperature and humidity values in black pine plantations and native forest twin plots were calculated for temperature as dif(temperature) = temperature black pine plantation - temperature native forest and for humidity as dif(humidity) = humidity black pine plantation - humidity native forest. Median values of dif(temperature) and dif(humidity) for every hour in every month were calculated and projected in graphs (package ggplot2).

\section{Results}

\subsection{Changes in Structural and Environmental Characteristics}

The obtained results indicate that Pinus nigra, as an edificator tree, changes the structural and environmental characteristics of forest communities (Table 1).

Table 1. Differences in structural and environmental characteristics of black pine plantations and native forests.

\begin{tabular}{cccc}
\hline & $\begin{array}{c}\text { Black Pine Plantation } \\
\text { Median } \pm \text { st. Deviation }\end{array}$ & $\begin{array}{c}\text { Native Forest } \\
\text { Median } \pm \text { st. Deviation }\end{array}$ & $\begin{array}{c}\text { Wilcoxon Test } \\
\boldsymbol{p} \text {-Values }\end{array}$ \\
\hline Tree layer cover (\%) & $70 \pm 11.6$ & $85 \pm 8.0$ & $<0.001$ \\
Shrub layer cover (\%) & $20 \pm 27.6$ & $10 \pm 21.3$ & 0.007 \\
Herb layer cover (\%) & $30 \pm 28.3$ & $50 \pm 28.2$ & 0.008 \\
Moss layer cover (\%) & $0 \pm 7.3$ & $0 \pm 1.3$ & 0.155 \\
Litter layer cover (\%) & $85 \pm 19.6$ & $80 \pm 27.2$ & 0.005 \\
Litter thickness (cm) & $3 \pm 1.8$ & $2 \pm 1.8$ & 0.039 \\
Canopy cover index (\%) & $67.05 \pm 9.3$ & $83.37 \pm 5.1$ & $<0.001$ \\
pH & $7.09 \pm 1.3$ & $6.94 \pm 1$ & 0.626 \\
\hline
\end{tabular}


The cover of the tree layer was significantly lower in black pine plantations than in the native communities. The cover of the shrub layer (e.g., Cornus mas L., Crataegus monogyna Jacq., Prunus spinosa L. or Rosa canina L. and juvenile tree species of adjacent communities) was much more variable in black pine plantations. The shrub layer cover values ranged from 0 to 85 percent, but it was generally better developed than that in native forests. In Pinus nigra plantations, the cover of the herb layer had lower cover, while the cover and thickness of litter were significantly higher (Figure 3). The cover of the herb layer was negatively correlated with the cover of the litter layer in black pine plantations (Spearman coefficient $=-0.531$ ). The cover of the moss layer did not differ significantly.

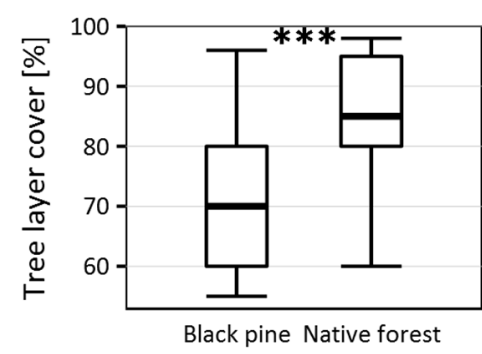

(a)

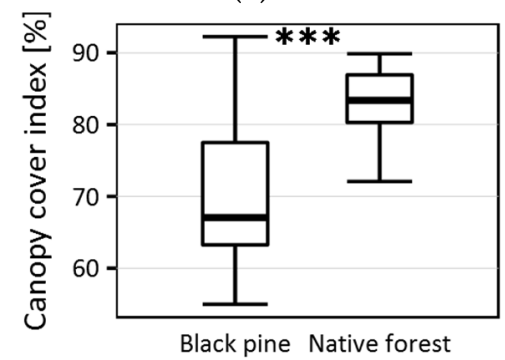

(d)

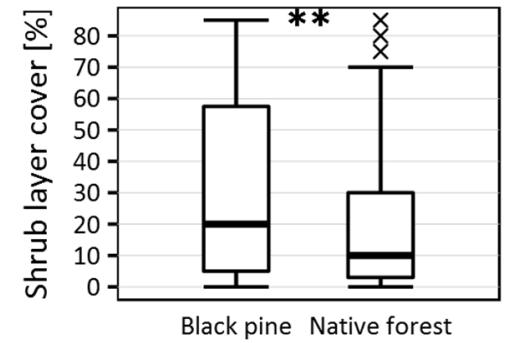

(b)

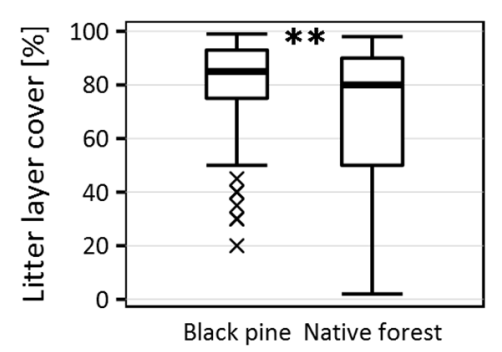

(e)

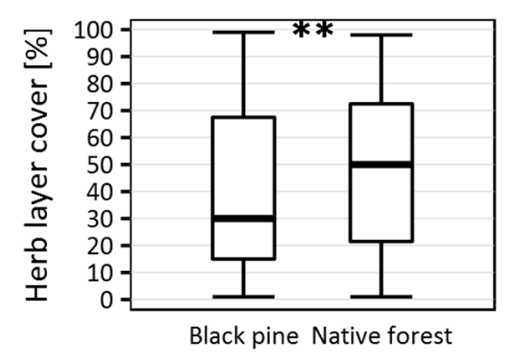

(c)

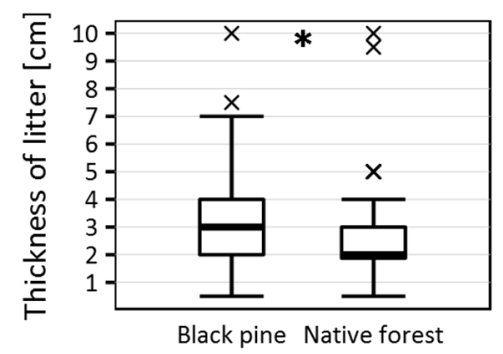

(f)

Figure 3. The structural characteristics of black pine vs. native twin plots compared using the Wilcoxon paired test. Significance codes $\left({ }^{*} p<0.05,{ }^{* *} p<0.01,{ }^{* * *} p<0.001\right)$ are according to Wilcoxon paired test. Outliers $(x)$ are presented. The comparisions of $(\mathbf{a})$ tree layer cover, $(\mathbf{b})$ shrub layer cover, $(\mathbf{c})$ herb layer cover, (d) canopy cover index, (e) litter layer cover and (f) thickness of litter are presented.

The black pine plantations had significantly lighter conditions. Not only was the estimated cover of the tree layer more open, but the gap light analysis also showed that they have a lower canopy cover index.

The directly measured soil $\mathrm{pH}$ in soil samples was not significantly different between forest types. The differences in structural and environmental characteristics of twin plots were not significantly different among vegetation groups.

The air temperature and humidity data measured by dataloggers under the tree canopy show that native forests have more balanced temperature and humidity during the day than black pine plantations after the formation of foliage. In the early spring (April), there was higher temperature and lower humidity in the undergrowth throughout the whole day in the native forests compared with the Pinus nigra plantations. After leaf development (from May to November), the temperature was lower during the day in native forests, while during the night, temperatures were higher in native forests. Humidity was higher throughout the day, and lower throughout the night in native forests (Figures 4-6). 


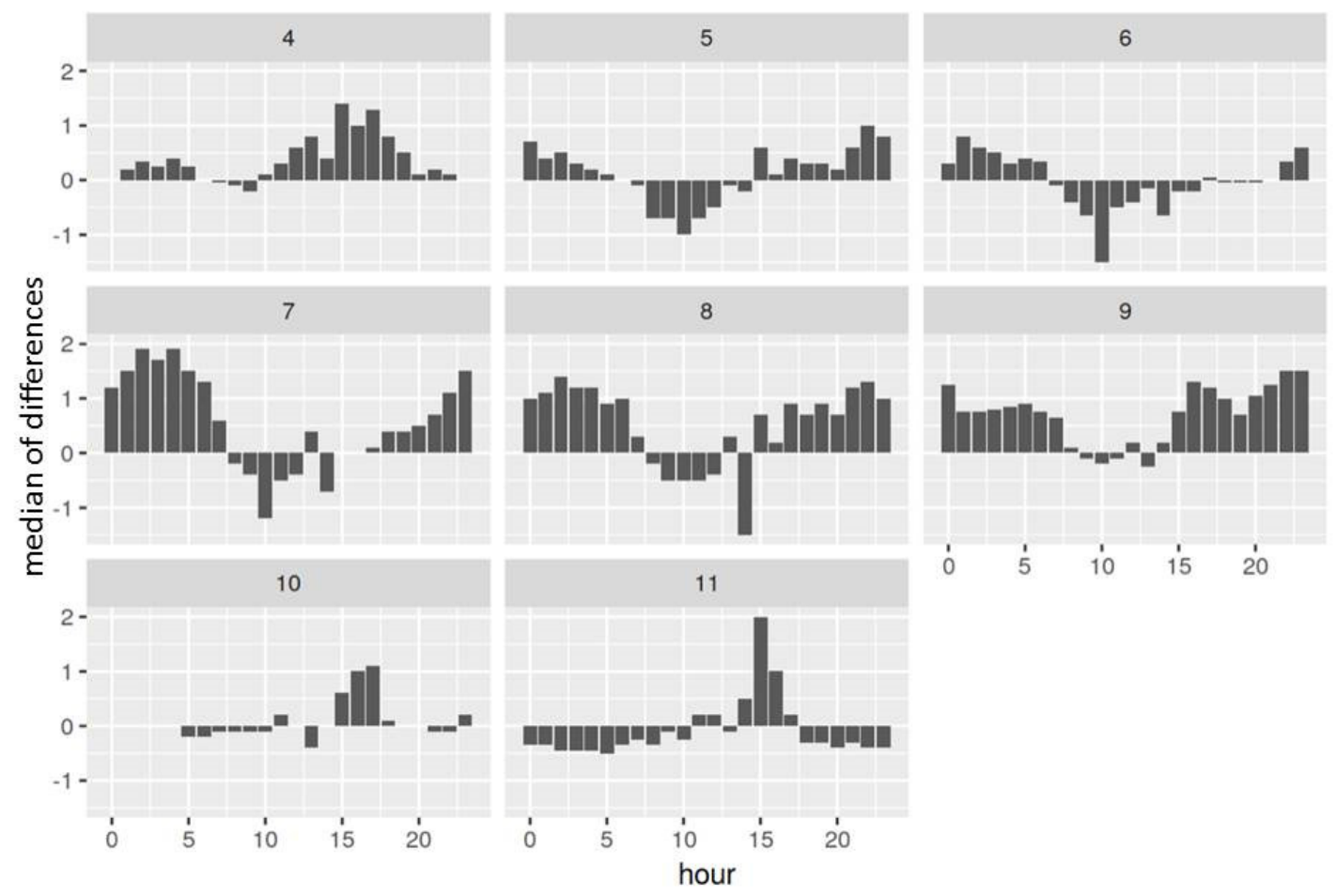

Figure 4. The medians of differences between black pine plantations and native forest communities in hourly measured temperature $\left({ }^{\circ} \mathrm{C}\right.$ ) in individual months (from April (4) to November (11)). The positive $\mathrm{Y}$ values indicate the higher temperature in native forests compared to black pine plantations.

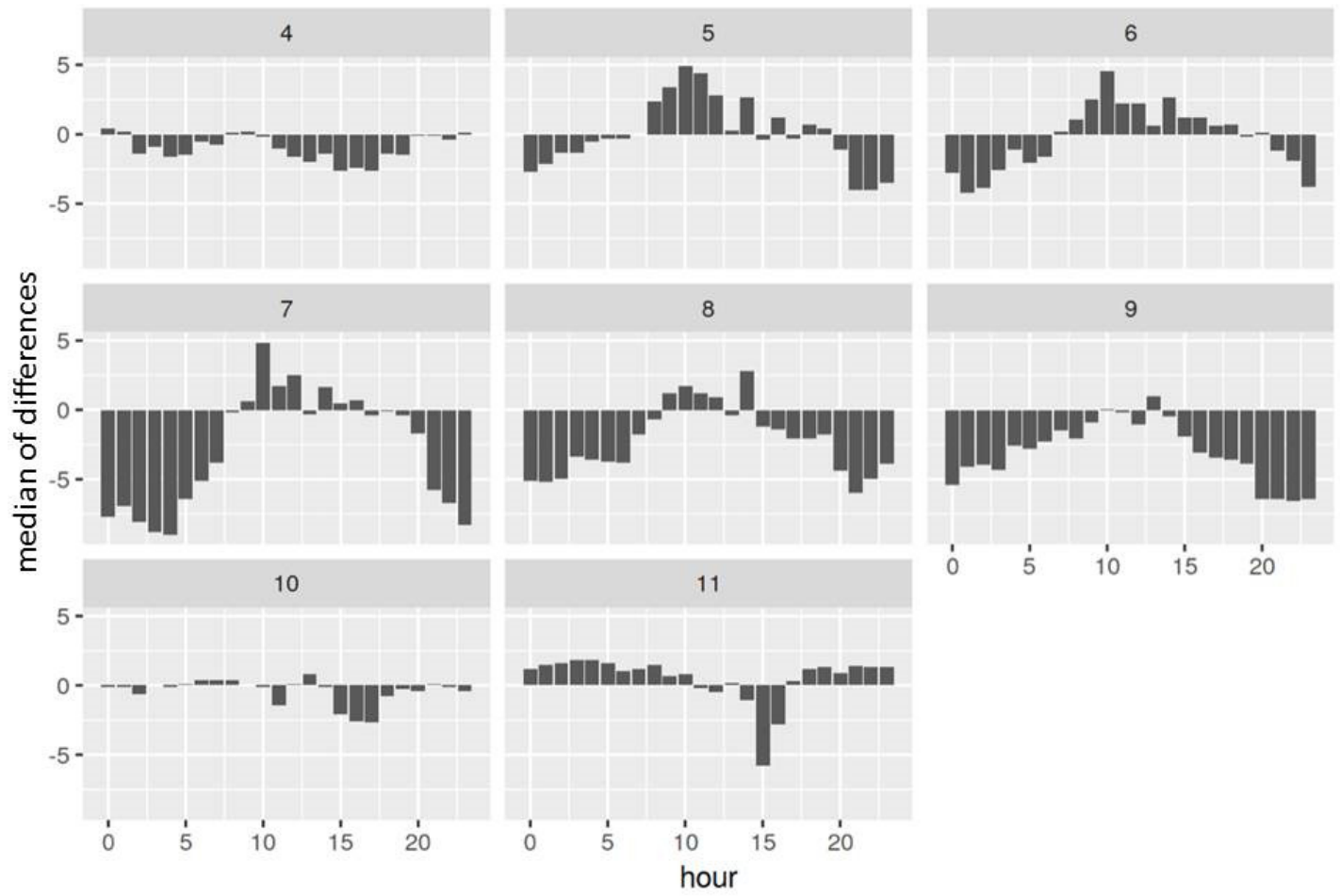

Figure 5. The medians of differences between black pine plantations and native forest communities in hourly measured humidity (\%) in individual months (from April (4) to November (11)). The positive Y values indicate higher moisture in native forests compared to black pine plantations. 


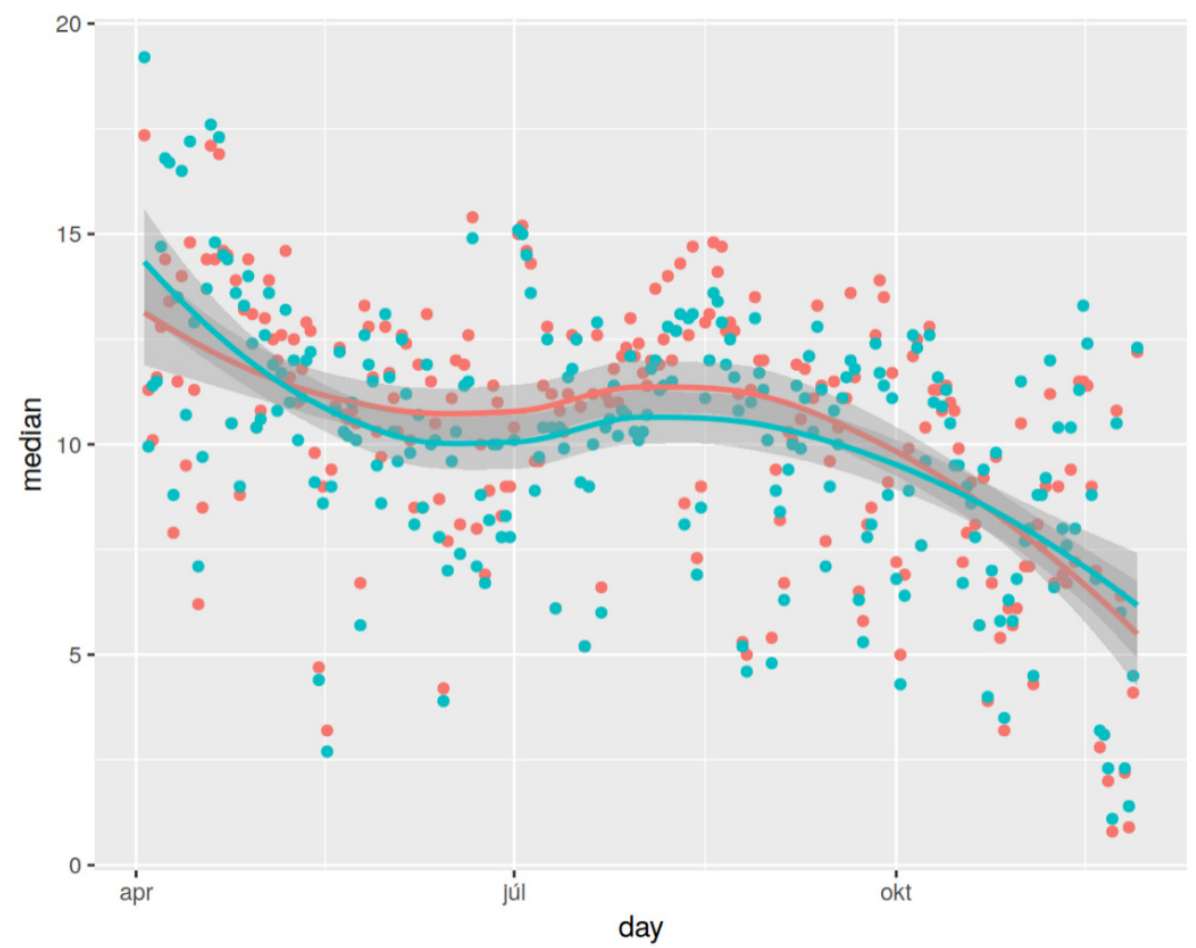

Figure 6. Medians of daily amplitudes of temperature in native forests (blue) and Pinus nigra plantations (red), visualised using loess smoothing with a confidence interval.

\subsection{The Differences in Undergrowth Species Composition}

PERMANOVA showed highly significant differences $(F=5.4587, p$-value $<0.001)$ in species composition between black pine plantations and native forests (Figure 7).

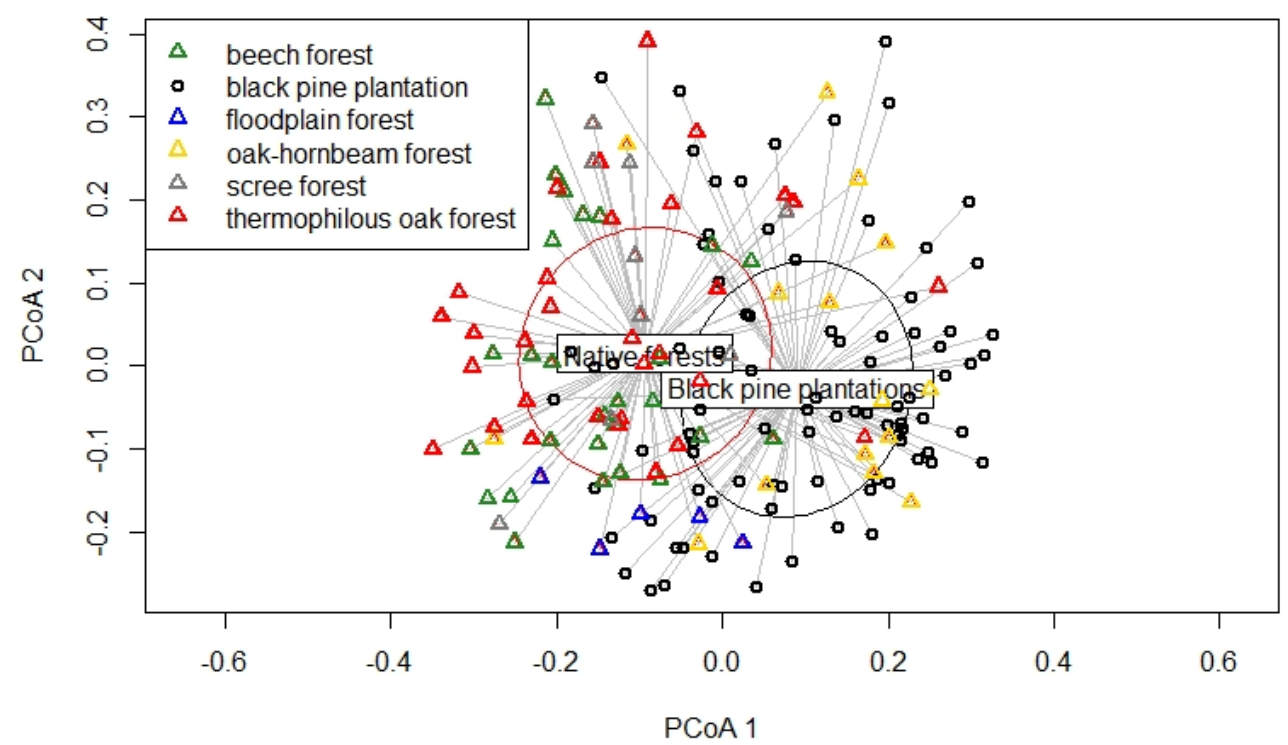

Figure 7. Significant differences in species composition of native forests and black pine plantations tested using PERMANOVA (Bray-Curtis index, 999 permutations), visualised as a scatterplot of the first two principal components with confidence ellipses.

The total species pool of the Pinus nigra plots (470) was higher than the species pool of the native plots (390). The comparison of twin plots showed no significant differences in the number of all species of the understory. However, there were clearly visible shifts in the species composition. The proportion of native species was higher in the undergrowth of native forest communities, while the absolute 
number and the relative abundance of neophytes and absolute number and the relative abundance of archaeophytes were higher in the undergrowth of black pine plantations (Table 2, Figure 8). The cover of native species was higher in native forest communities, while at the same time, the cover of archaeophytes was lower. However, the absolute number of native species and the cover of neophyte species were not significantly different between the two forest types. The absolute number, relative abundance and cover of diagnostic species and the absolute number, relative abundance and cover of constant species were significantly lower in black pine plantations (Table 2, Figure 9).

Table 2. Differences in species composition of black pine plantations and native forests.

\begin{tabular}{cccc}
\hline & $\begin{array}{c}\text { Black Pine Plantation } \\
\text { Median } \pm \text { st. Dev. }\end{array}$ & $\begin{array}{c}\text { Native Forest } \\
\text { Median } \pm \text { st. Dev. }\end{array}$ & $\begin{array}{c}\text { Wilcoxon Test } \\
p \text {-Values }\end{array}$ \\
\hline No. of all species & $37 \pm 13.4$ & $36 \pm 12.8$ & 0.245 \\
Absolute no. of native species & $31 \pm 11.9$ & $30 \pm 11.6$ & 0.557 \\
Relative abundance of native species (\%) & $93.33 \pm 6.4$ & $94.87 \pm 4.9$ & $<0.001$ \\
Cover of native species (\%) & $57.2 \pm 21.6$ & $76.5 \pm 20.2$ & $<0.001$ \\
Absolute no. of neophytes & $1 \pm 1.1$ & $0 \pm 0.9$ & $<0.001$ \\
Relative abundance of neophytes (\%) & $1.67 \pm 3.4$ & $0 \pm 2.8$ & 0.006 \\
Cover of neophytes (\%) & $0 \pm 4.7$ & $0 \pm 10$ & 0.147 \\
Absolute no. of archaeophytes & $1 \pm 1.5$ & $1 \pm 1.1$ & 0.024 \\
Relative abundance of archaeophytes (\%) & $3.13 \pm 3.8$ & $2.38 \pm 3.2$ & 0.038 \\
Cover of archaeophytes (\%) & $0.5 \pm 8.9$ & $0 \pm 4.6$ & 0.031 \\
Absolute no. of diagnostic species & $2 \pm 2.3$ & $3 \pm 2.7$ & 0.008 \\
Relative abundance of diagnostic species (\%) & $6.38 \pm 6.9$ & $8.33 \pm 8.6$ & $<0.001$ \\
Cover of diagnostic species (\%) & $3 \pm 13.5$ & $6.9 \pm 16.7$ & $<0.001$ \\
Absolute no. of constant species & $5 \pm 3.4$ & $5 \pm 4$ & 0.084 \\
Relative abundance of constant species (\%) & $14.81 \pm 10.2$ & $17.39 \pm 11.1$ & $<0.001$ \\
Cover of constant species (\%) & $8.2 \pm 16.8$ & $12.5 \pm 21.8$ & 0.002 \\
Ellenberg indicator value for light & $5.45 \pm 0.6$ & $5.2 \pm 0.6$ & $<0.001$ \\
Ellenberg indicator value for moisture & $4.64 \pm 0.4$ & $4.71 \pm 0.3$ & $<0.001$ \\
Ellenberg indicator value for temperature & $5.59 \pm 0.2$ & $5.59 \pm 0.2$ & 0.764 \\
Ellenberg indicator value for nutrients & $5.11 \pm 0.9$ & $5.21 \pm 0.7$ & 0.206 \\
Ellenberg indicator value for soil reaction & $7.13 \pm 0.3$ & $7.03 \pm 0.3$ & $<0.001$ \\
\hline
\end{tabular}

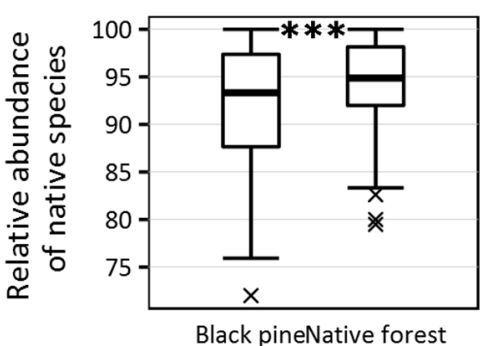

(a)

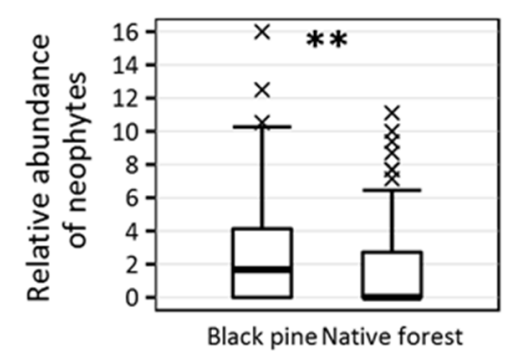

(b)

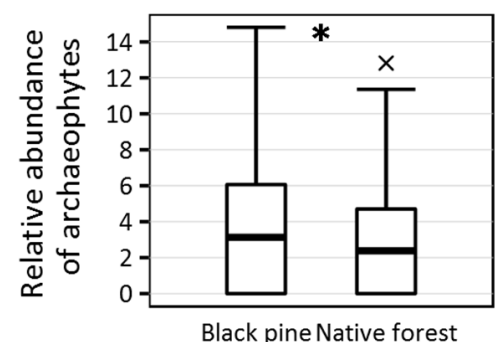

(c)

Figure 8. The diversity of black pine vs. native twin plots compared using the Wilcoxon paired test. Significance codes $\left({ }^{*} p<0.05,{ }^{* *} p<0.01,{ }^{* * *} p<0.001\right)$ are according to Wilcoxon paired test. Outliers $(\times)$ are presented. The comparisions of $(\mathbf{a})$ relative abundance of native species, $(\mathbf{b})$ relative abundance of neophytes and (c) relative abundance of archaeophytes are presented.

The analysis of the Ellenberg indicator values representing extrapolated requirement indices for target variables showed that the Pinus nigra plantations had more light-demanding species and fewer moisture-demanding species (Table 2, Figure 10). This trend was supported by the species composition, shown in the synoptic table (Table S1). Groups of heliophilous, thermophilous and xerophilous species, such as Anthyllis vulneraria L., Centaurea stoebe s. 1. L., Eryngium campestre L., Falcaria vulgaris Bernh., Festuca pallens s. 1. Host, Festuca stricta subsp. sulcata (Hack.) Pils, Leopoldia tenuiflora (Tausch) Heldr., Melica ciliata L., Leopoldia comosa (L.) Parl., Muscari neglectum Guss. ex Ten., Pimpinella saxifraga agg. L. or Thymus pulegioides subsp. pannonicus (All.) Kerguélen (Tables S1 and 
S2) created a distinct group of diagnostic species. The Ellenberg values for temperature and nutrients showed no significant differences between forest types. Although the directly measured $\mathrm{pH}$ was not significantly different, the Ellenberg soil reaction indicator value was significantly higher in the black pine plantations (Table 2, Figure 10).

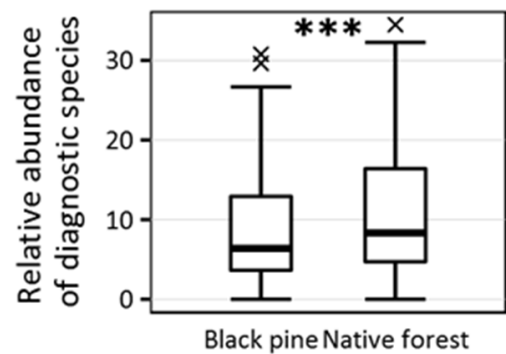

(a)

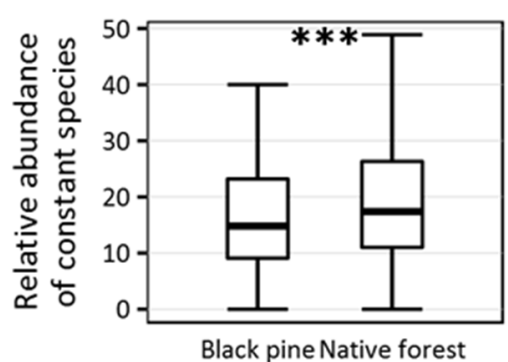

(b)

Figure 9. Diagnostic and constant species of black pine vs. native twin plots compared using the Wilcoxon paired test. Significance codes $\left({ }^{*} p<0.05,{ }^{* *} p<0.01,{ }^{* * *} p<0.001\right)$ are according to Wilcoxon paired test. Outliers $(\times)$ are presented. The comparisions of $(\mathbf{a})$ relative abundance of diagnostic species and $(\mathbf{b})$ relative abundance of constant species are presented.

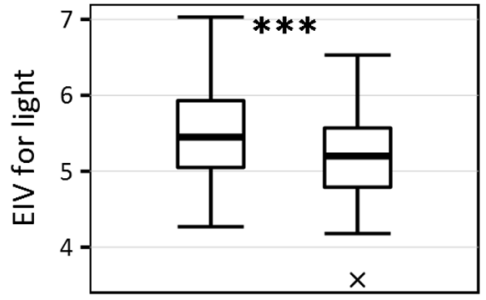

Black pine Native forest

(a)

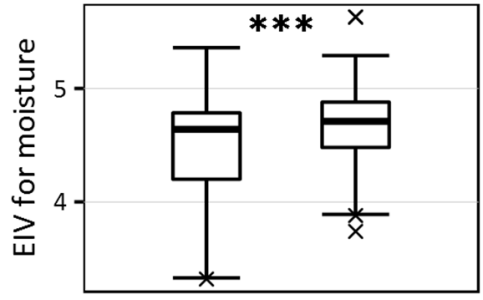

Black pine Native forest

(b)

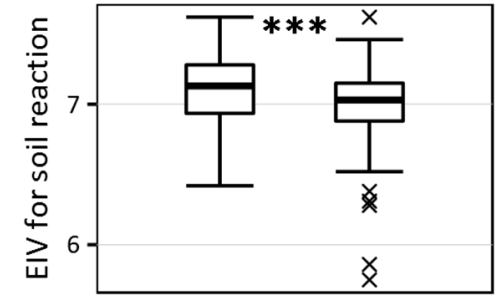

Black pine Native forest

(c)

Figure 10. Ellenberg indicator values of black pine vs. native twin plots compared using the Wilcoxon paired test. EIV—Ellenberg indicator value. Significance codes $\left({ }^{*} p<0.05,{ }^{* *} p<0.01,{ }^{* * *} p<0.001\right)$ are according to Wilcoxon paired test. Outliers $(\times)$ are presented. The comparisions of (a) Ellenberg indicator value for light, (b) Ellenberg indicator value for moisture and (c) Ellenberg indicator value for soil reaction are presented.

Kruskal-Wallis non-parametric analyses of variance and post hoc multiple comparisons of mean ranks for all groups, used to test, if there are significant differences among vegetation groups in tested variables, showed, that there are significant differences among vegetation groups in the cover of native species and EIV for temperature.

The biggest effect of black pine on the cover of native species was in beech and thermophilous oak forests.

Although EIV for temperature was not significantly different comparing the whole dataset, it was significantly different when comparing only twin plots of Pinus nigra plantations vs. thermophilous oak forests. Thermophilous oak forests have more thermophilous species composition.

\subsection{The Effect of Selected Factors on Diversity Change}

The dissimilarity between twin plots varied, and we tried to analyse factors that were associated with the dissimilarities. Based on the GLM, the altitude had a significant effect on the dissimilarity between compared twin plots $(F=6.988, p=0.0098)$. The higher the altitude, the lower the dissimilarity between the twin plots. At higher altitudes, twin plots were more similar, which means that black pine plantations were less different from the adjacent native forests at higher altitudes (Figure 11). Other factors (slope, radiation, aspect and community type at the alliance level) had no significant effects. 


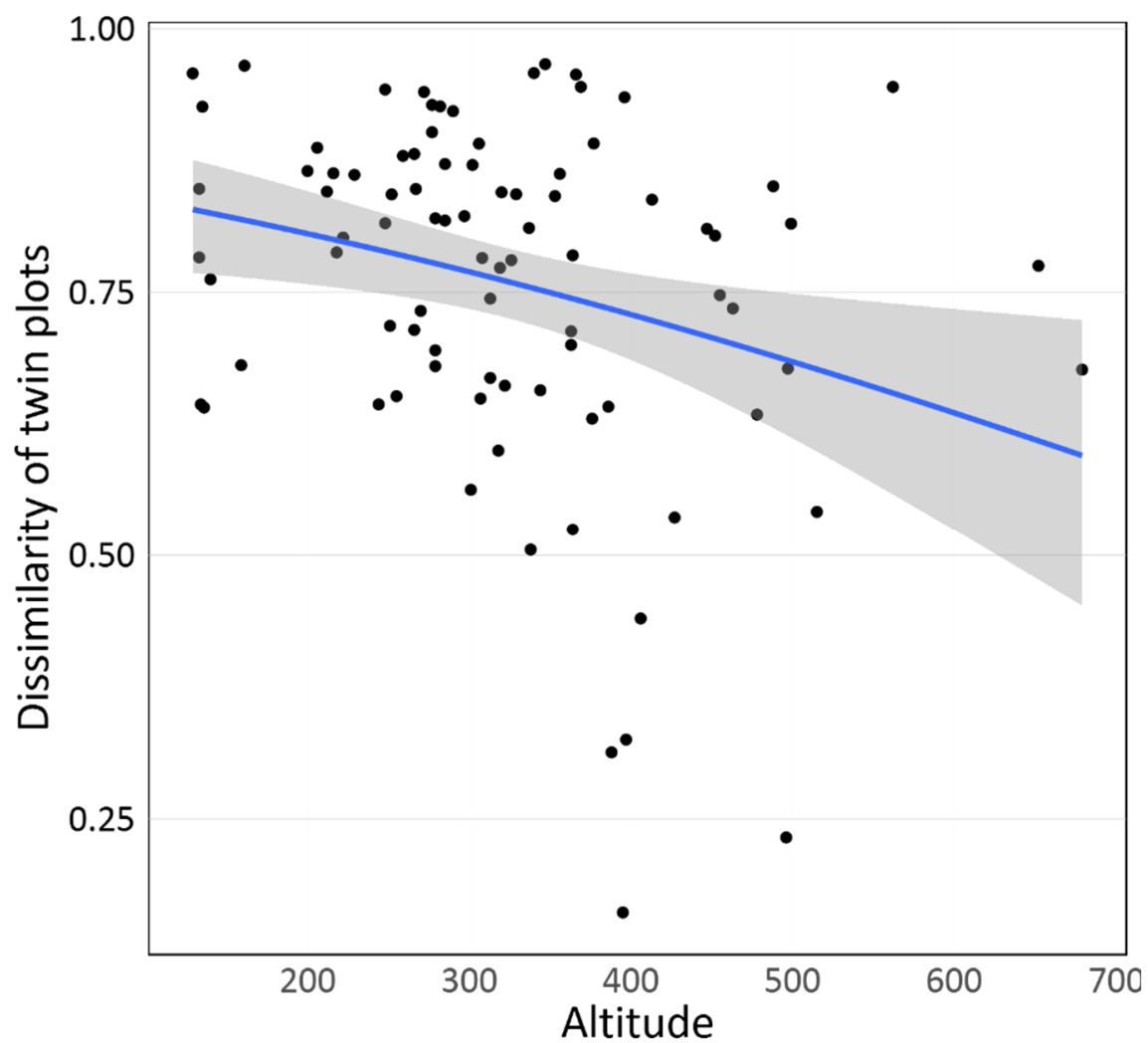

Figure 11. The effect of altitude on the dissimilarity of twin plots. According to the regression model (with quasibinomial distribution family and logit link function), at higher altitudes, twin plots are more $\operatorname{similar}(F=6.988, p=0.010)$.

\section{Discussion}

\subsection{Changes in Structural and Environmental Characteristics}

Our results indicate that the black pine plantations changed the structure and environment of stands in comparison with those of native plant communities in various ways. The canopy openness of black pine plantations led to better development of the shrub layer and expansion of light-demanding species (Table 1, Figure 4). The soil surface of black pine plantations was highly covered by litter created by needles, forming a thick layer (Table 1, Figure 4) that was correlated with the lower cover of the herb layer. Evergreen gymnosperm forests tend to have thicker forest floor layers, while some broadleaf trees induce more rapid decomposition of the litter, because of the chemical properties of their tissues, higher soil moisture and favourable conditions for earthworms [36].

Evergreen gymnosperms intercept more precipitation than deciduous angiosperms, due to their higher leaf area index [36]. Moreover, brighter conditions lead to more evaporation; therefore, black pine plantations hosted more xerotherm species corresponding to warmer and drier habitats. Together with unbalanced temperature and moisture fluctuations in black pine plantations, it seems that replacing native broadleaved communities with black pine plantations weakens the ability of forests to mitigate global warming. The protection of native forests and their processes enhance the carbon sink capacity of the forest, and, thus, contributes to mitigate climate warming. Moreover, it preserves the natural water regime and reduce flooding and drought $[37,38]$.

Many studies, e.g., References [39-41] have confirmed that coniferous species increase soil acidity. However, we have not confirmed this premise, as the directly measured soil reactions were not significantly different between forest types in our dataset. Soil acidification is a complex process that is dependent on various mechanisms. One of the main factors explaining this pattern could be the temporal aspect; the calcareous bedrock, where black pine is commonly planted, may slow the effect of 
acidification. Higher $\mathrm{pH}$ was measured under the coniferous trees in the papers of Ayres, et al. [42] and Mareschal, et al. [43] as well.

However, the occurrence of species with higher Ellenberg indicator values for soil reaction was higher in black pine plantations. This may be explained by the fact that many light-demanding species usually grow on limestone bedrock, so they generally indicate higher soil reaction. Such species frequently occur in black pine plantations, so that they could influence the analyses.

Changes in the structure and environmental characteristics of the native community were found in non-native black locust plantations. In addition to black pine plantations, the canopy in black locust stands is more open, and moreover, these forests are warmer and less humid throughout the day [8].

\subsection{The Differences in Species Composition of the Undergrowth}

Plantations of black pine cause changes in diversity at both the species and community levels. Although some species of potential native communities are tolerant of the changes in the environment from black pine plantations, our results showed that many diagnostic and constant species of the native forest are not able to live in such conditions. Turis and Valachovič [11] declare that species typical of potential natural vegetation and current contact stands can also survive in secondary woody communities, where Pinus nigra was planted mainly in the last century to prevent erosion. The same applies for floodplain forests [44]. The species pool of black pine plantations is further enriched by accidental species from surrounding communities and neophyte and archaeophyte species (Table S1).

Black pine and other non-native trees have been planted in Central Europe for the centuries [1]. Currently, some non-native forests form stable plant communities with typical species combinations in the undergrowth, e.g., black locust forests and Canadian poplar plantations (Medvecká et al. 2018 [4]). Black pine plantations planted outside their native range do not seem to have such specific diagnostic or constant species. They do not have even the species composition of the communities of black pine in the native distribution area, e.g., from the neighbouring Alps, Erica carnea L., Euphorbia saxatilis Jacq., Globularia cordifolia L., Cyclamen purpurascens Mill., and Ostrya carpinifolia Scop. [45]. Although non-native black pine forests occasionally host dealpine species, such as Sesleria caerulea (L.) Ard., the occurrence of these species is only occasional, and these stands cannot be assigned to black pine native alpine communities. Only species with wide ecological niches and large distribution ranges are common both for native black pine communities and non-native black pine plantations.

Similar negative influences on vascular plant species diversity and abundance, as we found in Pinus nigra plantations, were also found in other introduced tree species plantations. Quercus rubra L. stands in Poland decrease diversity and inhibit spontaneous restocking of native trees [7]. One of the most invasive species of the world, Robinia pseudoacacia L., has a negative effect on diversity as well [5,8,46-49]. Moreover, it leads to the homogenisation of forest communities [5,6]. Another example of the negative effect of non-native tree species planting is the cultivation of hybrid poplar (Populus $\times$ canadensis Moench). It is widely planted along the rivers of Europe, destroying the native riparian communities [50].

\subsection{The Effect of Various Factors on Diversity Change}

The results of the GLM indicated that altitude had a significant effect on the dissimilarity of the studied twin plots. Altitude is an important factor influencing species richness [51] and limiting the occurrence of neophytes [52,53]. Our results showed a significantly higher level of invasion in black pine plantations, but these invaded plantations were more common at lower altitudes where non-native species are widespread. The lower impact of black pine planting at higher altitudes could be explained by the lower propagule pressure of non-native plants in higher altitude areas. Although black pine can survive at a wide altitudinal range, the optimal altitude is between 800 and $1500 \mathrm{~m}$ above sea level [54]. The smaller dissimilarity between twin plots at higher altitudes may, therefore, be caused by more similar conditions, such as those in native black pine forests. Microclimatic conditions under black pine are dryer and warmer, and the day amplitude is larger. These factors are more challenging in 
warmer, lower-altitude regions, where these factors could be limiting for some typical forest species; thus, the plantation impact in low altitudes is more visible. In contrast, at higher altitudes where the climate is more humid, increases in temperature and decreases in moisture conditions caused by black pine are less limiting.

\section{Conclusions}

Non-native tree species planting is a substantial part of contemporary commercial forest practices. Non-native trees have numerous positive silvicultural properties, mainly related to production, such as fast growth or quality wood. However, forest ecosystems represent much more than wood production alone. They perform various ecosystem services that are becoming increasingly important, especially in the context of a changing climate.

The introduction of black pine outside its native range causes significant changes in the structure, environmental conditions and species composition in comparison with those of original native forest communities. Non-native Pinus nigra as an edificator tree creates significantly more open canopy stands in comparison to broadleaved native forest communities. Therefore, the shrub layer is denser. The needles of black pine create a thick litter layer, and, therefore, cause lower cover in the herb layer. Black pine plays a vital role in modifying local climate by altering air temperature and humidity. Both parameters had higher daily amplitudes in the black pine plantations, showing the lower ability of black pine plantations than of native forests to restrain climatic extremes.

The plantations of black pine are causing changes in diversity at both the species and community levels. They have a lower abundance of native species and a higher abundance of alien species and significantly lower absolute number, proportion and cover of diagnostic and constant species of compared native forests. The species composition consists of tolerant species and groups of heliophilous, thermophilous and xerophilous accidental species from surrounding non-forest communities. The dissimilarity of black pine plantations and neighbouring native forests decreases with increasing altitude.

Supplementary Materials: The following are available online at http://www.mdpi.com/1999-4907/10/7/548/s1, Table S1: Synoptic table of groups, Table S2: Tree layer species composition with a cover of individual species.

Author Contributions: K.M., I.J., K.H., J.M. (Jana Májeková), J.M. (Jana Medvecká), D.S., I.Š., M.Z. and M.Š. conducted the study design and field sampling, K.M., T.B., J.M. (Jana Medvecká) and M.Š. performed the statistical analyses, K.M. wrote the paper with contributions from K.M., I.J., K.H., J.M. (Jana Májeková), J.M. (Jana Medvecká), D.S., J.Š., I.Š., M.Z. and M.Š. through the drafting and review process.

Funding: This research was funded by the Ministry of Education, Science, Research and Sport of the Slovak Republic, grants VEGA 0119/19 and APVV 16-0431.

Acknowledgments: We would like to thank all the botanists who helped us find proper locations, helped us with the determination of species and provided valuable discussion on our topic, mainly Iva Hodálová, Pavol Mered'a, Tamás Rédei, Róbert Šuvada and the Vegetation Science Group of Masaryk University in Brno, Czech Republic.

Conflicts of Interest: The authors declare no conflict of interest.

\section{References}

1. Forest Europe. State of Europe's Forests 2015; FOREST EUROPE Liaison Unit: Madrid, Spain, 2015; p. 314.

2. Palik, B.; Engstrom, R.T. Species Composition; Cambridge University Press: Cambridge, UK, 1999; pp. 65-94.

3. Ujházy, K.; Ujházyová, M.; Hederová, L.; Máliš, F.; Martinák, M. Dominant tree species and stand density are the main drivers of plant diversity in managed fir-beech forests. In Book of Abstracts, Posters, 25th Meeting of the European Vegetation Survey; Agrillo, E., Attorre, F., Spada, F., Casella, L., Eds.; European Vegetation Survey: Rome, Italy, 2016; p. 107.

4. Medvecká, J.; Jarolímek, I.; Hegedüšová, K.; Škodová, I.; Bazalová, D.; Botková, K.; Šibíková, M. Forest habitat invasions-Who with whom, where and why. For. Ecol. Manage. 2018, 409, 468-478. [CrossRef] 
5. Benesperi, R.; Giuliani, C.; Zanetti, S.; Gennai, M.; Lippi, M.M.; Guidi, T.; Nascimbene, J.; Foggi, B. Forest plant diversity is threatened by Robinia pseudoacacia (black-locust) invasion. Biodivers. Conserv. 2012, 21, 3555-3568. [CrossRef]

6. Marozas, V.; Cekstere, G.; Laivins, M.; Straigyte, L. Comparison of neophyte communities of Robinia pseudoacacia L. and Acer negundo L. in the eastern Baltic Sea region cities of Riga and Kaunas. Urban For. Urban Green. 2015, 14, 826-834. [CrossRef]

7. Woziwoda, B.; Kopeć, D.; Witkowski, J. The negative impact of intentionally introduced Quercus rubra L. on a forest community. Acta. Soc. Bot. Pol. 2014, 83, 39-49. [CrossRef]

8. Slabejová, D.; Bacigál, T.; Hegedüšová, K.; Májeková, J.; Medvecká, J.; Mikulová, K.; Šibíková, M.; Škodová, I.; Zaliberová, M.; Jarolímek, I. Comparison of the understory vegetation of native forests and adjacent Robinia pseudoacacia plantations in the Carpathian-Pannonian region. For. Ecol. Manag. 2019, 439, 28-40. [CrossRef]

9. Isajev, V.; Fady, B.; Semerci, H.; Andonovski, V. EUFORGEN Technical Guidelines for Genetic Conservation and Use for European Black Pine (Pinus nigra); International Plant Genetic Resources Institute: Rome, Italy, 2004; p. 6.

10. Dixon, C.; Fyson, G.F.; Pasiecznik, N.; Praciak, A.; Rushforth, K.; Sassen, M.; Sheil, D.; Correia, C.S.; Teeling, C.; van Heist, M. The CABI Encyclopedia of Forest Trees; CABI, Ed.; CABI Publishing: Oxfordshire, UK, 2013. [CrossRef]

11. Turis, P.; Valachovič, M. Sekundárne lesné spoločenstvá s Pinus nigra na Slovensku. Acta Carpath. Occident. 2014, 5, 33-45.

12. Osono, T.; Azuma, J.-I.; Hirose, D. Plant species effect on the decomposition and chemical changes of leaf litter in grassland and pine and oak forest soils. Plant Soil 2014, 376, 411-421. [CrossRef]

13. Bazalová, D.; Botková, K.; Hegedüšová, K.; Májeková, J.; Medvecká, J.; Šibíková, M.; Škodová, I.; Zaliberová, M.; Jarolímek, I. Twin plots-Appropriate method to assess the impact of alien tree on understory? Hacquetia 2018, 17, 163-169. [CrossRef]

14. Forestry Geographic Information System. Available online: http://gis.nlcsk.org/lgis/ (accessed on 5 March 2019).

15. Braun-Blanquet, J. Pflanzensoziologie. Grundzüge der Vegetationskunde; Springer: Wien, Austria, 1964; Volume 3, p. 865.

16. Westhoff, V.; van der Maarel, E. The Braun-Blanquet approach. In Ordination and Classification of Communities; Whittaker, R.H., Ed.; W. Junk Publishers: Hague, The Netherlands, 1973; pp. 617-727.

17. Tichý, L. GLAMA-Gap Light Analysis Mobile Application. 2014. Available online: https://www.sci.muni.cz/ botany/glama/ (accessed on 2 February 2018).

18. Hennekens, S.M.; Schaminée, J.H. TURBOVEG, a comprehensive data base management system for vegetation data. J. Veg. Sci. 2001, 12, 589-591. [CrossRef]

19. Tichý, L. JUICE, software for vegetation classification. J. Veg. Sci. 2002, 13, 451-453. [CrossRef]

20. R Core Team. R: A Language and Environment for Statistical Computing; R Foundation for Statistical Computing: Vienna, Austria, 2016.

21. Euro+Med. Euro+Med PlantBase-The Information Resource for Euro-Mediterranean Plant Diversity. Available online: http://ww2.bgbm.org/EuroPlusMed/ (accessed on 1 March 2019).

22. Mucina, L.; Bültmann, H.; Dierßen, K.; Theurillat, J.-P.; Raus, T.; Čarni, A.; Šumberová, K.; Willner, W.; Dengler, J.; García, R.G.; et al. Vegetation of Europe: Hierarchical floristic classification system of vascular plant, bryophyte, lichen, and algal communities. Appl. Veg. Sci. 2016, 19, 3-264. [CrossRef]

23. Ellenberg, H.; Weber, H.E.; Düll, R.; Wirth, V.; Werner, W.; Paulißen, D. Zeigerwerte von Pflanzen in Mitteleuropa. Scr. Geobot. 1992, 18, 1-248.

24. Pyšek, P.; Danihelka, J.; Sádlo, J.; Chrtek, J., Jr.; Chytrý, M.; Jarošík, V.; Kaplan, Z.; Krahulec, F.; Moravcová, L.; Pergl, J. Catalogue of alien plants of the Czech Republic: Checklist update, taxonomic diversity and invasion patterns. Preslia 2012, 84, 155-255.

25. Terpó, A.; Zając, M.; Zając, A. Provisional list of Hungarian archaeophytes. Thaiszia 1999, 9, $41-47$.

26. Balogh, L.; Dancza, I.; Király, G. A magyarországi neofitonok időszerú jegyzéke, és besorolásuk inváziós szempontból. In Biológiai inváziók Magyarországon: Özönnövények. [Biological invasions in Hungary: Invasive plants; Mihály, B., Botta-Dukát, Z., Eds.; TermészetBÚVÁR Alapítvány Kiadó: Budapest, Hunghary, 2004; pp. 61-92.

27. Medvecká, J.; Kliment, J.; Majekova, J.; Halada, L.; Zaliberova, M.; Gojdičová, E.; Ferakova, V.; Jarolimek, I. Inventory of the alien flora of Slovakia. Preslia 2012, 84, 257-309. 
28. Protopopova, V. Sinantropnaya flora Ukrainy i puti ee razvitiya; Naukova Dumka: Kijev, Ukraine, 1991; Volume 1, p. 204. ISBN 825052143.

29. Protopopova, V.V.; Shevera, M.V.; Mosyakin, S.L. Deliberate and unintentional introduction of invasive weeds: A case study of the alien flora of Ukraine. Euphytica 2006, 148, 17-33. [CrossRef]

30. Jarolímek, I.; Šibík, J.; Hegedüšová, K.; Janišová, M.; Kliment, J.; Kučera, P.; Májeková, J.; Michálková, D.; Sadloňová, J.; Šibíková, I.; et al. Diagnostic, Constant and Dominant Species of the Higher Vegetation Units of Slovakia, 1st ed.; Jarolímek, I., Šibík, J., Eds.; Veda: Bratislava, Slovakia, 2008; p. 332.

31. Borhidi, A.; Kevey, B.; Lendvai, G. Plant. communities of Hungary; Akadémiai Kiadó: Budapest, Hunghary, 2012; p. 544.

32. Chytrý, M.; Douda, J.; Roleček, J.; Sádlo, J.; Boublík, K.; Hédl, R.; Vítková, M.; Zelený, D.; Navrátilová, J.; Neuhäuslová, Z.; et al. Vegetace České republiky 4. Lesní a křovinná vegetace; Chytrý, M., Ed.; Academia: Praha, Czech Republic, 2013; Volume 1, p. 551.

33. Wickham, H. ggplot2: Elegant Graphics for Data Analysis; Springer: New York, NY, USA, 2009; p. 213. [CrossRef]

34. QGIS Development Team. QGIS Geographic Information System. Open Source Geospatial Foundation Project. Version 2.18.26. 2018. Available online: https://qgis.org/en/site/ (accessed on 1 May 2019).

35. Chytrý, M.; Tichý, L.; Holt, J.; Botta-Dukát, Z.; Bruelheide, H. Determination of diagnostic species with statistical fidelity measures. J. Veg Sci. 2002, 13, 79-90. [CrossRef]

36. Augusto, L.; De Schrijver, A.; Vesterdal, L.; Smolander, A.; Prescott, C.; Ranger, J. Influences of evergreen gymnosperm and deciduous angiosperm tree species on the functioning of temperate and boreal forests. Biol. Rev. 2015, 90, 444-466. [CrossRef]

37. Naudts, K.; Chen, Y.; McGrath, M.J.; Ryder, J.; Valade, A.; Otto, J.; Luyssaert, S. Europe's forest management did not mitigate climate warming. Science 2016, 351, 597-600. [CrossRef]

38. Alkama, R.; Cescatti, A. Biophysical climate impacts of recent changes in global forest cover. Science 2016, 351, 600-604. [CrossRef]

39. Lindroos, A.J.; Derome, J.; Derome, K.; Smolander, A. The effect of Scots pine, Norway spruce and Silver birch on the chemical composition of stand throughfall and upper soil percolation water in northern Finland. Boreal Env. Res. 2011, 16, 240-250.

40. Berg, B.; Johansson, M.-B.; Ekbohm, G.; McClaugherty, C.; Rutigliano, F.; Santo, A.V.D. Maximum decomposition limits of forest litter types: A synthesis. Can. J. Bot. 1996, 74, 659-672. [CrossRef]

41. Eisalou, H.K.; Şengönül, K.; Gökbulak, F.; Serengil, Y.; Uygur, B. Effects of forest canopy cover and floor on chemical quality of water in broad leaved and coniferous forests of Istanbul, Turkey. For. Ecol. Manag. 2013, 289, 371-377. [CrossRef]

42. Ayres, E.; Steltzer, H.; Berg, S.; Wallenstein, M.D.; Simmons, B.L.; Wall, D.H. Tree Species Traits Influence Soil Physical, Chemical, and Biological Properties in High Elevation Forests. PLoS ONE 2009, 4, e5964. [CrossRef] [PubMed]

43. Mareschal, L.; Bonnaud, P.; Turpault, M.P.; Ranger, J. Impact of common European tree species on the chemical and physicochemical properties of fine earth: An unusual pattern. Eur. J. Soil Sci. 2010, 61, 14-23. [CrossRef]

44. Hamajová, V. Charakteristika floristicko-fytocenologických zmien v lužných lesoch širšieho okolia Podunajských Biskupíc. Dipl.(msc.), depon. PriFUK, Bratislava 2001, 1, 143.

45. Mucina, L.; Grabherr, G.; Ellmauer, T. Die Pflanzengesellschaften Österreichs; Gustav Fisher: Jena, Germany, 1993; Volume 1.

46. Šenkýř, M. Vliv nepůvodních listnatých dřevin na diverzitu bylinného patra. Master's Thesis, Masarykova univerzita, Brno, Czech Republic, 2015.

47. Trentanovi, G.; von der Lippe, M.; Sitzia, T.; Ziechmann, U.; Kowarik, I.; Cierjacks, A.; Pyšek, P. Biotic homogenization at the community scale: Disentangling the roles of urbanization and plant invasion. Divers. Distrib. 2013, 19, 738-748. [CrossRef]

48. Peloquin, R.L.; Hiebert, R.D. The Effects of Black Locust (Robinia pseudoacacia L.) on Species Diversity and Composition of Black Oak Savanna/Woodland Communities. Nat. Area. J. 1999, 19, 121-131.

49. Carter, J.; Ladd, C.; Lough, K.; Pamenan, F.; Pernecky, G. Assessing the allelopathy of invasive Robina pseudoacacia in northern Michigan forests. For. Ecosys. 2017, 1, 1-10. 
50. Botková, K.; Bazalová, D.; Jarolímek, I.; Zedníček, L'.; Petrášová, M. Canadian poplar plantations-threat to softwood floodplain forests. In Book of abstracts, Posters, 25th meeting of the European Vegetation Survey; Agrillo, E., Attorre, F., Spada, F., Casella, L., Eds.; European Vegetation Survey: Roma, Italy, 2016; p. 22.

51. Rahbek, C. The role of spatial scale and the perception of large-scale species-richness patterns. Ecol. Lett. 2005, 8, 224-239. [CrossRef]

52. Medvecká, J.; Jarolímek, I.; Senko, D.; Svitok, M. Fifty years of plant invasion dynamics in Slovakia along a 2,500 m altitudinal gradient. Biol. Invasions 2014, 16, 1627-1638. [CrossRef]

53. Walter, J.; Essl, F.; Englisch, T.; Kiehn, M. Neophytes in Austria: Habitat preferences and ecological effects. Neobiota 2005, 6, 13-25.

54. Piermattei, A.; Renzaglia, F.; Urbinati, C. Recent expansion of Pinus nigra Arn. above the timberline in the central Apennines, Italy. Ann. For. Sci. 2012, 69, 509-517. [CrossRef]

(C) 2019 by the authors. Licensee MDPI, Basel, Switzerland. This article is an open access article distributed under the terms and conditions of the Creative Commons Attribution (CC BY) license (http://creativecommons.org/licenses/by/4.0/). 